\title{
Social Relations in Rural China
}

From Village Head to Petitioner: The Case of Wu Boliang

\section{Catherine Capdeville-Zeng}

\section{CpenEdition}

\section{Journals}

Electronic version

URL: http://journals.openedition.org/chinaperspectives/7349

ISSN: 1996-4617

\section{Publisher}

Centre d'étude français sur la Chine contemporaine

\section{Printed version}

Date of publication: 1 June 2017

Number of pages: $59-68$

ISSN: 2070-3449

\section{Electronic reference}

Catherine Capdeville-Zeng, "Social Relations in Rural China », China Perspectives [Online], 2017/2

2017, Online since 01 June 2018, connection on 28 October 2019. URL : http://

journals.openedition.org/chinaperspectives/7349

(C) All rights reserved 


\title{
Social Relations in Rural China
}

\author{
From Village Head to Petitioner: The Case of Wu Boliang
}

\section{CATHERINE CAPDEVILLE-ZENG}

\begin{abstract}
The Wu Boliang affair reported in the Chinese media several years ago is symptomatic of the complex socio-political situation in the Chinese countryside. Wu Boliang was one of the first entrepreneurs from his village to develop the cultivation of mandarin oranges, and in 1993 and 1997 he acquired several orchards under the "responsibility system" in order to make them productive with the help of the township. But the latter did not provide him with the necessary funds in time, obliging him to borrow in his own name to cover the wages of the agricultural workers and the purchase of pesticides, fertiliser, etc. As the years went by and debts piled up, the township still did not reimburse him, forcing Wu Boliang to undertake legal proceedings. Although he immediately won his case against the township, the sums owed to him were still not paid, and he had no other option but to become a petitioner. In 2014, 20 years after the signing of the contract, the matter was finally settled. My in-depth analysis follows this particular case over a period of about ten years, and gives a detailed insight into the intricate interplay between the various mechanisms within the hierarchical pyramid of the Chinese society. This enables me to study the behaviour of the agents - both individuals and institutions.
\end{abstract}

KEYWORDS: China, rural society, family, legal proceedings, debt, $\min$ (the people) and guan (official circles).

\section{Introduction}

$\mathrm{O}$ n 23 June 2010, China Youth Daily published a long article by Jin Yongquan accompanied by several photographs and entitled "How a peasant family was made bankrupt." (1) In the commentary setting out the details of the "Wu Boliang affair" are the following main points:

From 1993 to 1997, Wu Boliang signed a responsibility contract with the Sanxi local government to develop some mandarin orange orchards. Because the local government did not honour its commitments laid down in the contract, and after a period of negotiation, Wu Boliang as a party to the responsibility contract, and in the name of the other signatories, borrowed a sum of money from the local credit co-operative (xinyongshe 信用社) (2) and from private individuals on behalf of the local government in order to cover the wages of the peasant employees, the cost of necessary construction materials, and other expenses, totalling 640,000 yuan.

Further down the article states:

As soon as the contract was signed, the local government changed its position!

And:

Since Wu Boliang's demands for repayment had no effect, on 14 January 2000 , he started proceedings against the Sanxi local government at the Fuzhou municipal court. This became the first instance in this mountainous region of a legal action by a "man of the people" ( $\mathrm{min}$ 民) against "official circles" (guan 官), and it caused a sensation.

Wu Boliang, a peasant and for many years the head of his village, is a remarkable person who was the first from his area to have the temerity, or the insouciance, to launch a legal claim for the repayment of the cost of his investment in the orchards belonging to the township, which he had obtained under a "responsibility" contract chengbao 承包. (3) These proceedings started in 2000, and Wu Boliang won immediately, but this outcome produced no result; the sums borrowed were not reimbursed and he was forced to become a petitioner. The affair dragged on over a long period, reaching its final outcome in 2014.

This article recounts and analyses the personal experience of a single man as an example of the social relations involved in local village society. His is not an isolated case, for there are many examples of "members of the people starting proceedings against officials" (min gao guan 民告官) in Chinese newspapers and legal journals in particular. The Chinese database for written academic records (CNKI) lists 1,796 sources under the key words min gao guan, of which 171 concern the "difficulty" (nan 难) that people have had in bringing cases against officials. (4) The example of Wu Boliang illustrates the social complexity affecting rural society within contemporary Chinese society. The study offered here takes an anthropological approach to reflect on the practices and values shaping the actions undertaken by the different protagonists, and on the sociological relationships influencing each of them, over and above their personal relations. The aim is not so much to depict the dysfunctions being described as to understand how the social relationships between the protagonists operate, and the nature of their underlying ideology as well as their sociological coherence.

The first-hand sources for this article are based on notes compiled in situ since 2002, during regular research work into the nuo ceremonial theatre

1. Jin Yongquan, "Yige nongmin jiating shi zenme zoudao pochan bianyuan de" (How a peasant family was made bankrupt), Zhongguo qingnian bao (China Youth Daily), 23 June 2010, p. 8.

2. The main banking organisation for loans to the peasantry.

3. The "responsibility system," established as part of China's economic reforms, allows various levels of state authorities to lease land or enterprises to individuals, enabling them to develop and profit from them outside the control of the state.

4. According to an enquiry on 30 December 2015. Previous enquiries carried on CNKI and other Chinese websites in 2013 and 2014 also reported large numbers of similar results, showing the importance of these social issues. 
(nuoxi 倠戏) in the village of Shiyou. ${ }^{(5)}$ It also makes use of the joint work entitled The Last Chinese ${ }^{(6)}$ by Chen Tong and Liu Chun (for the written texts), directed by Jin Yongquan (mentioned above), who took the photographs. This collection of articles portrays Shiyou through a description of its theatre and inhabitants, including Wu Boliang in particular. Although based on its authors' fieldwork in Shiyou in 2001, it is not actually a scientific document but rather a travel narrative recording the experiences of some young Chinese city-dwellers among the rural population. Its title, The Last Chinese, seems to evoke James Fennimore Cooper's historical novel, The Last of the Mohicans, which dealt with the disappearance of the Native Americans and created a sensation when it was published in 1826.

Abundant use is also made of Jin Yongquan's newspaper article, subtitled "How a peasant family was driven into bankruptcy." This article played a major role in the outcome, because its writer conducted further enquiries on the spot, making it a trustworthy written basis for the main facts, and it has been a helpful complement to data gathered by myself. Information on Wu Boliang is also available on the internet. An article by Chinese legal experts gives an in-depth study of his case. ${ }^{(7)}$

The affair had repercussions, especially in Jiangxi Province, and of course locally in the county of Nanfeng. For this reason, no new elements are introduced in my article, which is concerned with giving an anthropological interpretation of the facts. My aim is to throw light on some underlying but important aspects that have been left out of the published material and the websites. My objective is not the journalistic one of showing up the faults or virtues of the protagonists, but rather the scientific one of trying to understand the social relations at the heart of the affair.

I open with the local context, covering the geographical and the sociopolitical situation of the village, Wu Boliang's biography, and the major outlines of the legal process. Then there is a detailed account of each of the different levels playing a role in the affair: the family, the village, the township, the county, the municipality, and in the end the capital, Beijing. After that comes a study of the factors at the heart of the affair: money, the issues of face and honour, and work. The article concludes with a summary of the analysis developing the themes of the representation of the debt, the role of the negotiation and bargaining, and the agents' area of intervention in contemporary Chinese society.

\section{The village of Shiyou and the enquiry}

Shiyou is located in Sanxi Township of Nanfeng County under the municipality of Fuzhou in Southeast Jiangxi, which is an agricultural province in Southeast China. The village is about a dozen kilometres from the county capital. The region is hilly with some medium-sized mountains, and used to be mainly a producer of rice in the paddy fields of its valleys, in addition to a few other secondary crops. Over the last 20 years or so it has seen the widespread and intensive cultivation of mandarin oranges, which has brought considerable prosperity to the inhabitants. In fact, the small sweet mandarins were formerly cultivated in a few orchards, and used to be sent as an annual offering to the imperial court. This tradition lives on because every year the county still sends a certain amount of its best, carefully selected mandarins directly to the centre. In the winter some of them can also be bought in all the major Chinese cities under the name of "Nanfeng mandarins."

The village of Shiyou has about 1,300 inhabitants, the principal lineage of which includes $75 \%$ of the populace surnamed Wu, with the remainder con- sisting of several other family names. Formerly the village was run by lineal dignitaries who formed a council based on kinship relations responsible for organising the main village temple dedicated to the god of the nuo, and of directing the annual ritual theatre. In 1949, these dignitaries were removed from their administrative and political duties, retaining only their control over the theatre, while the Communist Party took over running the village. During the Cultural Revolution, the theatrical performances disappeared for about 15 years and only reappeared in the late 1970s. The descendants of the old dignitaries then recovered control over the theatre, but under the leadership of the Party. The social relations between the villagers became more complicated as the link with the Party was combined with the traditional kinship system. Nonetheless, the kinship relations are still very present, as well as the ideology and the family practices that go with them. These constitute a social bond that is both very strong (comprising a variety of duties) and hierarchical (the distinction of fathers and dignitaries).

I first visited Shiyou in February 2002 to spend the New Year festival there and to study its theatre. I was with two Chinese photographers, and we telephoned Wu Boliang, who was the village head at the time and greeted us warmly. Since then I have returned to the village nearly every year, at first for the New Year festivities and later, over several years, for the summer months. I was therefore able to observe the undercurrents of the affair throughout those years, although many of the more intimate details were still unknown to me.

\section{Wu Boliang's biography}

\section{According to The Last Chinese:}

Formerly Wu Boliang was one of the poorest peasants in Shiyou village, to the point that his father considered arranging a "son-in-law marriage" (8) for him. [...] Nowadays Wu Boliang is the richest man in the village, and was the first to build a two-storey house there.(9)

The biographical details below were taken from Wu Boliang's own words, as well as from his autobiography and some information in The Last Chinese. At the time of the first redistribution of land and household goods in the 1950s Wu B's paternal grandfather received a bed and two rooms -but each located in houses at some distance from one another. Wu Boliang's father was married in 1950, and he was born in 1952. He was the eldest child, with four younger brothers and a sister. At eight years old he began to help his father by taking the buffalos out to pasture, or making them turn the grindstone or draw water from the well. At the age of ten he entered primary school, where he studied for four years. But in his fifth year the Cultural Revolution broke out, and Wu Boliang became a young Red Guard wearing a red armband

5. Some of the results have been published in Catherine Capdeville-Zeng, Le théâtre dans l'espace du people - une enquête de terrain en Chine (The theatre in the people's space - an enquiry on the ground in China), Paris, Les Indes Savantes, 2012.

6. Jin Yongquan, Chen Tong, and Liu Chun, Zuihou de hanzu (The Last Chinese), Beijing, Zhongyang bianyi chubanshe, 2001.

7. Guo Bingqi and Liao Shenji, "Xi 'min gao guan' nan de yuanyin - cong zhidu cengmian jinxing sikao" (Analysing the reasons for the difficulties faced by men of the people against the officials - a reflexion on the system), The Journal of Fujian Institute of Political Science and Law, Vol. 23, No. 1, March 2005, pp. 65-68.

8. A "son-in-law marriage" (or "uxorilocal marriage") is one in which a man, who is usually poor, goes to live with his father-in-law, instead of the wife coming to live with her husband's family: in such cases the name of the maternal grandfather is passed onto his grandsons by birth, and a certain scorn is attached to those sons-in-law who are unable to pass on their family name to their own sons.

9. Jin Yongquan, Chen Tong, and Liu Chun, Zuihou de hanzu (The Last Chinese), op. cit., p. 185. 
and going with his comrades to other people's houses to "smash the four olds" (po si jiu 破四旧). He told me that he now regrets these former activities, but acknowledges that he understood nothing at the time and only followed the movement. But his studies were over for him in any case, and he started working the land with his father. He quickly obtained such good and copious results that he won the respect of the other peasants. That allowed him to become an agricultural technician, first for the village and then, in 1973, for the township. In 1976, in order to avoid a "son-in-law marriage," he married his cousin, the daughter of his maternal uncle. He then joined a group of agricultural technicians sent by Nanfeng County to Hainan Island to study the technique of fertilising mandarin seeds. Returning home in 1977 after seven months in Hainan, he was put in charge of seed fertilisation by the people's commune; this gave him an income of 24 yuan a month, which was a considerable wage at the time, and better than the work points given for working the land. His elder son was born in 1978 and a second one in 1980, after which he adopted a daughter. In 1979 he built a new house for his numerous family (which included his parents, his unmarried and married brothers with their wives and children, and his own wife and children), which was the first house in the village to be built of bricks and with more than one storey. 1981 saw the first partial "family division" (fenjia 分家), ${ }^{(10)}$ which in terms of accommodation amounted only to building separate kitchens for his married brothers, while he remained the elder brother responsible for the family fortunes and especially for the education of his younger brothers.

With the decollectivisation of 1982, all the land was redistributed to the peasants and a quota was allotted to every family member. Since Wu Boliang's family had many mouths to feed, their allocation amounted to about ten $m u^{\left({ }^{(11)}\right.}$ which made it a large enterprise in local terms. After that redistribution, the family underwent its second and final family division. Wu Boliang gave up his position as the township agricultural technician to "return home" (hui jia 回家) and focus on his land and his crops. He quickly began to earn more and more money. In 1983 he was among the first to obtain a village orchard under the "responsibility system." In 1985, mandarin oranges fetched three mao ${ }^{(12)}$ per half kilo, and he earned 1,000 yuan; the following year they fetched six mao and he earned 3,000 yuan. In 1986 he signed a new responsibility contract with the township for a 50 mu orchard plus an 800 mu pine forest. In 1987 he took on a new village orchard, followed by another one in 1991. The winter of 1991 was unusually cold, and $85 \%$ of the mandarin trees in the county were frozen, but in $1990 \mathrm{Wu}$ Boliang had started to produce mandarin saplings, of which he had already 80,000 in hand to sell for 1.5 yuan each. This earned him 120,000 yuan in 1992, and he became the richest peasant in the village. That year he joined the Party and built a new private house for himself with three storeys and two wings. It was the tallest building in the village, where he could comfortably lodge his two sons when they got married.

In 1991 a national propaganda review published an article under the heading: "He has enhanced the brilliance of Sanxi," (13) which set out Wu's agricultural career since 1983 and ended with the following:

The charming township of Sanxi raised up Wu Boliang. And in return Wu Boliang has solidly developed and led activities that have given Sanxi its mandarins, pigs, melons, and other fruits, bringing riches to his impoverished village relatives. ${ }^{(14)}$

In 1994 he was put in charge of the township lands. In 1995, he was proposed for election as "village secretary" (cun shuji 村书记) of Shiyou, but only won the position of "assistant secretary" (cun fushuji 村副书记) and "assistant village head" (fucunzhang 副村长). This position was ratified by the village elections, and he kept it until 2005, when he was not re-elected. In local terminology, these titles carry precedence in themselves, with "secretary" taking first place and "village head" coming second, while the unflattering "assistant" usually remains unsaid, so Wu Boliang is generally called the "village head," taking second place behind the "village secretary." But it appears that he was really the political mover and shaker in village affairs. It was during those years that he created and developed a pesticide and fertiliser business, with one store in the village and another in the township capital, and then yet another in the county capital.

Between 1993 and 1997 he signed another responsibility contract with the township for the development of two orchards. This was the contract that would give rise to his difficulties.

\section{From the contract to the legal proceedings and their resolution}

Not having any access to the responsibility contract signed by the two parties, I have no knowledge of its precise terms. Wu Boliang informed me that he was in charge of management and leadership, while the township's investment was the supply of land and finance. It is not clear how the two parties shared the profits, or whether there were any profits. In fact, it takes about five years for a tree to begin providing mandarins, and the contract was not renewed after its five-year agreed term. The actual sums committed, and the interest accrued, remain opaque. Wu Boliang's explanations on that matter are still obscure to me.

Among the creditors, a distinction has to be made between the township credit co-operative on the one hand, and the different informal lenders, including three important tradesmen, on the other. The credit co-operative led by the township was Wu Boliang's primary creditor. After lending him some funds, it then refused to grant him any further sums, although these were necessary to develop the orchards. This lack of support by the credit co-operative led Wu Boliang to seek other sources of credit, which explains the growing number of creditors. When some of these private creditors called on him to repay their loans in the late 1990s, and Wu Boliang was unable to do so, he was himself forced to take legal action against the township.

On 29 February 2000, the Fuzhou municipal tribunal gave its verdict: Wu Boliang won his case and the township was ordered to repay the sums he had borrowed, in a single payment within eight days.

This gave rise to a series of negotiations and back-and-forth between Wu Boliang, the township, and the county. Using the justification that Sanxi is a "poor township" that already had difficulties paying its officials and teachers, the township refused to make a single repayment. It went on to make irregular payments of several thousand, or tens of thousands of yuan, stretched out over nineteen instalments and amounting to a total of about 300,000 yuan by 2010 , which was not even half the amount claimed and granted by the judgement. The problem for Wu Boliang was that with these

10. Among the Chinese peasantry, the "family division" is the equal sharing between brothers of the father's possessions (land, buildings, tools etc.), allowing the sons to gain economic autonomy, after which their households are independent of each other.

11. The $m u$ is an area of arable land equivalent to 666.6 square metres.

12. Equivalent to a tenth of a yuan.

13. "Sanxi yin ta zeng se" (He has enhanced the brilliance of Sanxi), Laoqu jianshe, 6 June 1991.

14. Ibid., p. 47. 
small sums he could not repay his creditors on time. He was therefore obliged to "roll over" the loans, and to "dismantle the eastern wall to repair the western one" (as the aforementioned article on "the peasant family" puts it). By 2010, the total amount he had to reimburse had risen to 880,000 yuan, payable to 27 creditors. The article states that:

The loans generated exorbitant interest payment demands: the 70,000 yuan lent by the township cooperative in 1994 and 1995 alone created more than 260,000 yuan in interest by 2010 . As for the sums borrowed from private individuals at usurious rates, they are so large that they are truly frightening. ${ }^{(15)}$

After 2000, in addition to his visits to the township and county government offices, the Fuzhou municipal court, and lawyers' offices, Wu Boliang also went to the "offices for letters and visits" of Nanfeng County, Fuzhou Municipality, the provincial capital, Nanfeng, and then in the autumn of 2009, the national capital, Beijing. These "offices for letters and visits" (16) are a peculiarly Chinese administrative institution, to which one can send letters of complaint or go in person to complain about an injustice. The office then handles the matter by sending demands to the local authorities to act in some way or another. By 7 June 2010, Wu Boliang had visited these offices 94 times, and had been to various government offices to seek justice on 240 occasions, without any tangible results. In September 2009, tired of these judicial delays, Wu Boliang hired a lawyers' office located in the municipality to draw up a full account of all the overdue sums. They amounted to over 600,000 yuan. Confronted by this figure, in early 2010 the township indicated its willingness to reimburse the initial sum but not more than 50,000 yuan in interest. But then, according to the aforementioned article, "the working group on implementing the court's decision in favour of $\mathrm{Wu}$ Boliang against Sanxi Township, Nanfeng County, acknowledged that in addition to the initial amount, it had to pay interest amounting to 300,000 yuan." Nonetheless, this acknowledgement was not followed by any payment. On the contrary, again according to the same article, "On 10 June, a township official admitted during an interview that the interest repayment demanded by Wu Boliang was legal, but he asked the journalist to act as an intermediary to advise Wu Boliang to ask for less."

In desperation, Wu Boliang contacted jin Yongquan in Beijing, who had directed the joint publication, The Last Chinese. He came to spend several days in Shiyou to conduct enquiries. Then his article appeared on 23 June 2010 in China Youth Daily. The next day, the article was immediately picked up on several influential websites, and Nanfeng was subjected to great pressure. The county head took charge of the affair to try to resolve the problem. It seemed about to be settled, but the repayments were still not forthcoming. In 2011 and 2012 some sums were repaid, but Wu Boliang challenged the amounts, considering them insufficient.

In 2013 the affair still dragged on, with a further 400,000 yuan still missing. Finally, in 2014 the township signed a contract with Wu Boliang stipulating that a new orchard would be assigned to him under a 50 -year responsibility contract, but after a lapse of three years (when the orchard would become available, being currently ceded to another person). This new orchard would be a reparation for all Wu Boliang's losses, and the income from the sales of its mandarins would allow him to reimburse his creditors. The affair was finally resolved. Wu Boliang accepted this outcome, although he had to wait until 2017 to take over the orchard and therefore had to keep his creditors waiting.
The social relationships involved in the affair

\begin{tabular}{|c|c|c|c|}
\hline individual & geren 个人 & Wu Boliang & 吴伯亮 \\
\hline family & jia 家 & $\begin{array}{c}\text { Surname Wu (and } \\
\text { relations on the } \\
\text { female side) }\end{array}$ & $\begin{array}{c}\text { 吴姓 } \\
\text { (和姻亲亲戚) }\end{array}$ \\
\hline village & cun 村 & Shiyou & 石邮 \\
\hline township & xiang 乡 & Sanxi & 三溪 \\
\hline county & xian 县 & Nanfeng & 南丰 \\
\hline municipality & shi 市 & Fuzhou (Linchuan) & 抚州(临川) \\
\hline province & sheng 省 & Jiangxi-Nanchang & 江西 - 南昌 \\
\hline National capital & shoudu 首都 & Beijing & 北京 \\
\hline
\end{tabular}

\section{Family relationships}

The Wu Boliang affair was first and foremost a "family" matter in the broadest sense.

In order to deal with the loss of support from the credit co-operative, Wu Boliang borrowed at first, he told me, "from [his] brothers, [his] sisters, [his] wife, [his] sister's husband (brother-in-law), and from friends and relatives" (including among the latter, some tradesmen). All of the people mentioned in this list were outside the independent household established by Wu Boliang through the family division. They included members of the same generation, not only agnatic relations (his brothers) but also relations on the female side: his wife's sisters and their husbands. This showed the strong mutual aid links between such people, which help to resolve a relative's financial problems. In the Chinese countryside - and this is still the case nowadays in Shiyou - the members of a family are tied by obligations to provide mutual aid according to the income of each of them. Loans are only taken from those who are able to lend, and the latter have a duty to lend in case of need. It is very difficult to get out of these obligations, because each person's income is more or less well known to all. The family remains the main source of mutual aid as it represents a reliable centre of relationships. The closer the relationship, the more confidence one has. This way of seeing things is extended to friends, and then to more distant relations. The Wu Boliang affair clearly shows that the family replaces the failing co-operative structures - so it is each person's refuge against an arbitrary fate.

The family, or the nuclear family household, also represents the centre of a network that branches out and extends to those on its outer periphery, which means that there is no clear separation between an individual, his family, and the rest of society. On the contrary, there is a continuous relationship based on relative social distances. This relational indeterminacy of the Chinese family, which has drawn the attention of certain writers and especially the anthropologist Fei Xiaotong in his major work

15. Jin Yongquan, "Yige nongmin jiating shi zenme zoudao pochan bianyuan de" (How a peasant family was made bankrupt), Zhongguo gingnian bao (China Youth Daily), 23 June 2010, p. 8.

16. These have been studied especially by Isabelle Thireau in Les ruses de la démocratie en Chine protester en Chine, (Democracy's Ruses in China - How the Chinese Protest), Paris, Seuil, 2010. There have been many studies in English, especially: Neil Diamant, Stanley Lubman, and Kevin O'Brien (eds), Engaging the Law in China: State, Society, and Possibilities for Justice, Redwood, Stanford University Press, 2005; Philip Huang, Civil Justice in China: Representation and Practice in the Qing, Redwood, Stanford University Press, 1996; Carl Minzner, "Xinfang: An Alternative to the Formal Judicial System," Stanford Journal of International Law, Vol. 42, 2006, pp. 103-179. 
on rural China, is clearly seen in other spheres, especially in material possessions. ${ }^{(17)}$

For example, in March 2010, Wu Boliang went to see a lawyer to draw up a certificate filing for bankruptcy. That certificate covered all the property of his family enterprise: their land and trees, their own house, their pesticide and fertiliser stores. In order to face his debts, he seriously considered selling all his goods - his own and those of his businesses. Similarly, the authorities found it quite legitimate for Wu Boliang to use his properties and "personal" income to repay the township's "public" debts. As a pesticide salesman, Wu Boliang was considered to be "rich" by both the villagers and the authorities, and the latter therefore found it "normal" for him to use his other resources to pay back the debts from his orchards. Whether from the viewpoint of the villagers or of the township and the county, Wu Boliang as an individual and Wu Boliang as a family enterprise were two entities who were not clearly distinguishable. And that is precisely the question that Wu Boliang himself had difficulty answering: to what extent was he, as an individual and as a family man, responsible for the township debts?

When he momentarily considered declaring himself bankrupt, he was making himself (and his family enterprise) personally and completely responsible for the debts of the township. If he had followed through with this action, it would have put him in contradiction with his struggle over all those years to recover the money owed to him by the township - that is to say, to get them to recognise Wu Boliang as a real, equal, and independent partner, and not as a subordinate who could be manipulated at will. For its part, the township administration, through its minor reimbursements, partially acknowledged its own responsibility while also tying responsibility to Wu Boliang both as an individual and as a family and leaving them to deal with the missing funds on their own. The Wu Boliang affair is noteworthy for the difficulty experienced by its protagonists in clearly separating matters belonging to the "private" sphere, including that of the family, from those belonging to the "public" domain and the state. On the one hand, the township administration considered Wu Boliang to be a subordinate member of the "township family" who could be treated as an inferior subject to its decisions, and on the other hand Wu Boliang himself showed that he shared this outlook when he did not hesitate to borrow in his own name to settle a debt that was not his own - for instance, when he considered selling his personal belongings to settle the debts. The whole difficulty of the affair lies in the inability of its main protagonists, the township on one side and Wu Boliang on the other, to envisage a relationship between themselves as autonomous beings. Social relations based on a familial and hierarchical vision are still very present, and the affair shows that Fei Xiaotong's observation in 1947 is still true today. Indeed, the lack of a clear distinction between the individual, the family, and the expanded local group - in this instance, the township - is undoubtedly an important factor for understanding how the protagonists could have ended up where they did that is to say, how Wu Boliang could have borrowed so much from his relatives and friends, over and over again, to settle a debt that was not actually his.

This difficulty in conceiving personal independence in relation to the family, and in relation to the authorities, is also made clear in Jin Yongquan's article. It contains repeated examples where the term for "family," jia, replaces "peasant" or "person," or where Wu Boliang's name is added to it, sometimes also designating his "real" family. In the course of translating for this article, my difficulty in rendering the meaning of the term "family" re- veals its dimensions, for in either French or English one would simply say "a peasant," or else one would name the individual to remove all imprecision. It is obvious from the way the article is written that the boundary between Wu B. the individual and his "family" is not clearly defined, and in the same way, one never really knows who is a real member of this family, which seems to include not only members of the nuclear family but also the whole Wu lineage, along with relatives on the female side. This imprecision, beyond the figurative style that it may represent, closely reflects the preponderance of the family over the individual, a Chinese reality that has caused much ink to flow. The interesting point is that in this respect, even nowadays after the Communist revolution and modernisation, the family is still at the heart of society in the countryside.

\section{The village}

The porous nature of the financial relations between relatives extends from the family level to the village. The family's capabilities are very limited, hence the necessity of recourse to friends and relatives, and to more distant acquaintances to whom kinship relations are extended.

In his autobiography published in The Last Chinese Wu Boliang says that during his village headship, "When there was not enough money in the village coffers I lent it my own money." (18) This phenomenon of financial intertwining of individuals, families, neighbours, friends, and relatives is the general case in rural society. When a peasant needs money to invest in building a house, or sending his children to school or university, his first choice is not to turn to a bank but to his relatives and friends in the village. Borrowing from close relatives means avoiding interest payments, but borrowing from friends or more distant acquaintances in particular frequently involves "usurious rates." Then why not borrow from the bank? Perhaps because of what might happen in the event of nonrepayment: "Two days ago they took off to jail a man from our village who could not pay back the 7,000 yuan that he owed to the co-operative." (19) Another reason, pointed out in the article "Informal Lenders and Rural Finance in China: A Report from the Field," (20) is that the agricultural bank and credit co-operatives often refuse loans to peasants whom they consider insolvent, preferring to lend to local or even urban small enterprises; unlike these sources, the "informal lenders," who represent a real institution under different guises in the Chinese countryside, know the peasants personally and have the means to get their loans back, if necessary through the seizure of their crops, tools etc. So the informal lenders make up for the insufficiencies of the financial organs of the state, and the peasants are not put off by their high rates because, in addition to supplying their real needs, the basis of their relationship is personal acquaintance and trust.

So it turns out that in village life everyone is both lender and debtor to others, on a small or larger scale. Credit is a way of life in itself, and it is the main social relationship in the countryside because it is a form of exchange, and exchange is at the basis of village life, as the Sino-American anthropologist Yan Yunxiang

17. Fei Xiaotong, Xiangtu Zhongguo (Rural China), Shanghai, Shanghai renmin chubanshe, 1947. Translated into English as From the Soil: The Foundations of Chinese Society, Berkeley, University of California Press, 1992, 176 pages.

18. Jin Yongquan, Chen Tong, and Liu Chun, Zuihou de hanzu (The Last Chinese), op. cit., p. 201.

19. Ibid., p. 203.

20. Zhou Li and Hiroki Takeuchi, "Informal Lenders and Rural Finance in China: A Report from the Field," Modern China, Vol. 36, No. 3, 2010, pp. 302-328. 
(1996) shows. (21) However, Yan Yunxiang does not tackle the credit aspect, and he limits himself to describing the exchange of "gifts," except when he happens to mention the case of a gift being transformed into credit:

When a certain villager had some financial problems, he turned to one of his good friends for financial support. With a great deal of effort, the friend found a relative who would lend money to the first villager to resolve his problem quickly. However, things turned bad when the latter discovered that he would have to pay interest on the loan. [...] An interest-bearing loan is only applicable between people who do not have good relations [...]. (22)

In the 1990s, China began its remarkable economic take-off, and in the villages there was an increase in the number of financial exchanges. It is difficult to invest without financial resources, as the example of Wu Boliang showed when he needed money to meet the developmental needs of his orchards. So, following a very common practice in the Chinese countryside, he turned to his "relatives and friends" for a form of financial aid about which it is difficult to know whether it is in fact a gift (23) or a loan, it being understood that both forms have to be repaid either with interest or by various other means (mutual help, exchanges of skills or favours, etc.). There is no clear distinction between the social relationship of mutual aid and the contractual financial relationship, facilitating the recourse to loans that are considered from the outset the kind of customary exchange of gifts deeply rooted in the Chinese village rather than genuine contracts. This fluidity in exchanges also depends on the specific situation of the countryside economy. In village society there are no salaries. After the harvest, the village resounds with money received by the peasants in one lump sum from mandarin orange sales. The money must then be saved. As the cost of living is not very high in the countryside, even though expenses pile up regularly, the earnings from the mandarins can be considerable. If one person does not use up his money straight away, others come to borrow from him, and that can be a good investment, especially since the lender puts them under an obligation.

That is how Wu Boliang used his connections to borrow, which was for him the only conceivable solution, given the failure of financial organisations to support him. It is quite extraordinary that his creditors could finally reach the grand total of twenty-seven. This figure indicates the breadth of his relationship networks and their ramifications throughout the family, the village, the township, and the county.

\section{In the township}

What happened next? Why did the township government not reimburse Wu? The current organisation of administration in China is part of the problem. From the top of the state government down to the lowest village level, China has two complementary institutions: the Party and the civil government. Although the members of the civil government are all Party members, their government post always comes second to the corresponding position in the Party. At the village, township, and county levels, the secretary of the Party committee takes precedence over the governmental heads. Although this administrative power stops at the township level, the Party is present everywhere in China, even down to the village level. Shiyou has about 20 Party members who meet in a committee of village affairs, and the village leaders are chosen from among their number. But the choice is made by the township government (it nominates the Party secretary and approves the candidates for village elections). The county government selects the township leaders, and the municipality chooses the county leaders, and so on upwards. The general rule is that leaders are chosen "from above" (shangmian 上面).

There is, however, a clear cut-off point between villages and townships, because villagers chosen to be heads of their village are generally unable to become state functionaries by rising up through the higher levels. Their peasant status means that village heads and secretaries usually cannot rise within the hierarchy - or can only do so with difficulty. (24) By the same token, the villages are ruled by their own village Party members and not by cadres sent "from above," whereas from the township level upwards the localities are administered by cadres appointed by the higher authorities, who are not usually native to them. And China's national policy is to rotate these cadres regularly (usually every three years) to prevent them from forming excessively close ties with those under their control. Consequently, as Wu Boliang is quoted as observing in the article on his case, "Very often the new officials do not acknowledge the steps taken under their predecessors, and everything has to start again!" That is indeed where one of the problems of the affair lies, obliging Wu on numerous occasions to meet with different administrative teams. Exacerbating the problem of township officials' noninvolvement in village affairs, the difference in status between a peasant and officials from the higher township body, even if the former is a village head and a Party member, makes him a second class citizen, which the higher-level citizens do not fail to turn to their advantage.

The township officials who had been in charge of the responsibility contract were moved elsewhere in the county, and it seems they never had to answer personally for Wu Boliang's case. However, from 2002 to 2003, the newly appointed officials did undertake to resolve the affair by setting up a "negotiated contract" with him, providing for the township government to guarantee a yearly repayment of 50,000 yuan until the full repayment of the debt, with the orchards as guarantee and collateral. But this solution fell by the wayside for reasons that are still not clear (but it was partly taken up again in 2014 and allowed the affair to ultimately be settled).

Nonetheless, it is quite clear that, for all its postponements, the township did in effect repay part of the debt, and that it tried to resolve matters without success. So it acknowledged its debt, but in the face of the enormous sums involved, it showed itself unable to handle all the complex details. In fact, the township was entirely reliant financially on the county as its superior authority.

\section{From the township to the county}

It is the county level that has administrative, political, and therefore financial power. The townships are merely the basic cogs in the machine, and they generally operate from a large village called the "township headquarters" (xiangli 乡里), whereas the county administration is located in a "county headquarters" (xiancheng 县城). All the local cadres from the dif-

21. Yan Yunxiang, The Flow of Gifts - Reciprocity and Social Networks in a Chinese Village, Redwood, Stanford University Press, 1996.

22. Ibid., p. 143.

23. In his famous "Essay on the Gift: Form and reason for exchange in archaic societies," first published in 1925, the ethnologist Marcel Mauss shows that the gift operates within a system of three stages: giving, receiving, and giving back, it being understood that what is "given" and what is "given back" may differ in kind and value. In China, for example, it is common to offer objects or money in exchange for favours. See Marcel Mauss, Essai sur le don - Forme et raison de l'échange dans les sociétés archaïques (An essay on the gift: the form and reason of exchange in archaic societies), Paris, Presses Universitaires de France, 2007, 248 pp.

24. In 2012, I was told that from then on, villagers under 45 years old could in some circumstances apply to join the administration and attend training sessions in the Party schools. 
ferent administrations are assembled in one place, and the township cadres often go there to get their orders, and spend most of their time there.

The county capital is also where the office of letters and visits is located. This office does not open daily, and its hearings are announced publicly in advance. Wu Boliang attended on numerous occasions, and the article on his case opens with an account of his 94th visit:

[...] in order to be present at the reception day for the county leader Zhu Honggen, which had been announced previously. [But] he was disappointed because it was not the county chief who appeared on that day. It was Rao Aihua, the secretary of the Sanxi township Party committee, who was sent to receive the petitioners. ${ }^{(25)}$

It appears that this administration is controlled by the same leaders who run the county: the petitioners whose demands have not been met by their leaders turn to that office in the hope that it will find a solution, but in fact it is run by the same people. Wu Boliang said with a sigh, "They are very polite in that office, but they do not solve the problems" (quoted in the same article on his case). The government and administrations of the townships and the county are their own little world: a few dozen cadres who roll on from post to post, looking for chances of promotion to the county or the municipality. Currently the county headquarters has only about a hundred thousand inhabitants, and a walk down the high street is often an encounter with acquaintances. However, the county is itself dependent on its higher authority, the municipality, which participates in the appointments of its secretary and county leaders.

\section{From the municipality to the province, from the province to Beijing... and back again to Nanfeng}

How important is the municipality? Fuzhou, formerly called Linchuan, and whose inhabitants still prefer to use its old name, is located about a hundred kilometres north of Nanfeng, on the road to the provincial capital of Nanchang. It is a famous historical city, which enjoyed a certain notoriety under the Song dynasty. But, being too distant from Nanfeng, this municipality does not seem to have much influence on the county peasantry. For them, Fuzhou is another world, where another language is spoken. So why did Wu start his legal proceedings before the court in Fuzhou? The answer is: because the large sums at stake would be given more adequate attention by a higher administrative level. And why did he hire a lawyer from Fuzhou? Wu Boliang put more trust in the officials and lawyers from the "municipality" of Fuzhou than in those from the "county" of Nanfeng. In the normal run of things, the verdict of a municipal court, being at a higher level, should have more authority over the officials of the lower county level.

But Wu Boliang did not stop at the municipality. To put his demands before the office of letters and visits, he also went to Nanchang, the capital of Jiangxi province, and then in 2009 to the national capital, Beijing. That was because he had heard that a political decision by the central government was ordering administrative bodies in the regions to deal with petitioners' problems, so he thought that he had a chance. The national office of letters and visits received him, noted his demand, and sent the file back to the county. That is to say, to the same people. But it seems that the order from this office to repay the township's debts to Wu Boliang did have some effect, even though it was probably not decisive.

This circular track shows the way in which Chinese society is "integrated" and "hierarchized": there is a direct vertical line from the village to the town- ship, to the county, to the municipality, to the province, and finally to the leadership of the state. But a local problem must be handled and resolved at the local level, so the intervention by the Fuzhou court, by the lawyers, and by the national office of letters and visits had limited effect because the file always came back to the local officials. The legal system and the office of letters and visits are not independent and have no power to ensure that their verdicts are put into effect. According to the article on this affair: "[And] even an official of the Fuzhou court told Wu Boliang privately that difficulties in getting the judgements put into effect are a common phenomenon, and that it was already quite an achievement for him to be recovering the initial amount." Nonetheless, the verdict of the court and the follow-up from the office of letters and visits were indispensable for $\mathrm{Wu}$ Boliang, and over all those years he depended on them to get his rights respected.

\section{The heart of the affair: Money, face, honour, and work}

These are Wu Boliang's own words in 2001, quoted in his autobiographical statement in The Last Chinese:

I won my case before the intermediary court, but nobody believed that the township was really going to pay me back; they said, "You, Wu Boliang, have made the township lose face, so how can they give you your money back?" Before the hearing, nobody thought I could win. Deep down I was afraid, but I believed in justice. I said to the creditors pursuing me, "Don't be afraid, as soon as the township reimburses me, I will reimburse you." The court judges came to make enquiries on four occasions. Up until now the township had only paid me back 6,000 yuan, and I myself put in 3,000. And do you know how much they owed me? Over 400,000! I could not avoid paying myself; even if I were to die, how could I be a man in my next reincarnation? And even for those 6,000 yuan, the judge said to me, you absolutely must not tell outsiders because, he told me, the township wanted to save face. I couldn't tell anyone, but how could I explain that to my creditors? (26)

An important element in the affair was indeed the protagonists' need to save face, ${ }^{(27)}$ that of the institutions as well as the leaders. Such legal proceedings caused them to lose face, which was all the more reason for them to be hostile to Wu Boliang for uncovering and displaying the affair in public. But Wu Boliang himself also lost face, as he wrote in a letter to me in 2012. This document throws light on how he still saw things 12 years after the trial:

Because I was first thrown forward and then thrown back caused me a loss of over 5 million yuan, including the cost for the proceedings, the hotel visits, the food and other expenses amounting to over 300,000 yuan, the sums borrowed from private individuals at incremental rates whose interest for those 12 years amounted to more

25. Jin Yongquan, "Yige nongmin jiating shi zenme zoudao pochan bianyuan de" (How a peasant family was made bankrupt), art cit.

26. Jin Yongquan, Chen Tong, and Liu Chun, Zuihou de hanzu (The Last Chinese), op. cit., pp. 203-204.

27. On the question of "face" in Chinese society, the article by Hu Hsien Chin, "The Chinese Concept of Face," American Anthropologist, Vol. 46, 1944, pp. 45-64, although a bit old-fashioned, is still an excellent exposition of the different dimensions and the structural importance of this idea in social relations. 
than 1.5 million yuan; the losses from my investments in the orchards reached more than 1.5 million, while the losses from my pesticide business were again more than 1.5 million. In addition, the whole business ruined my health and cost me a great deal; in medicines alone, the amount was more than 300,000 yuan over those 12 years. Now I am completely unable to work and cannot meet my own needs. It has all caused me a lot of psychological suffering. Whereas formerly I received the title of "pioneer in science and technology in aid of the poor," I have now been driven into bankruptcy, my life is a failure, I no longer have the energy to develop my orchards and agricultural technology, my health is ruined, and my family enterprise has been halted in its tracks. The saddest thing is that I cannot pay off all my debts on time and my word is no longer accepted, so I have lost my honour and no longer have face in the sight of others.

Wu Boliang begins this narration by adding up all the sums involved. They come to around 5 million yuan, which is much more than the amounts mentioned earlier. Now his accountancy mixes together the loans and their interest, the amounts spent on the legal proceedings and the visits to the office of letters and visits, the loss of potential investment in his orchards and stores, and his expenditure on his health. The overall damages cover the economic outcomes (the arrested development of Wu Boliang's business), the medical consequences (the deterioration of his health), and the psychological result (his incalculable suffering). But the worst thing, with which Wu Boliang concludes his list of downfalls, is his loss of honour and face.

In the end, the failure to reimburse not only led to financial insolvency but brought about social effects on the life and honour of the individual. In losing face, the individual falls apart, he no longer has honour, people no longer speak to him and he no longer dares to speak to others, so he becomes a kind of outcast. Jin Yongquan tells us in his article, "When we walk in the village, Wu Boliang avoids meeting the villagers, and those whom he knows very well no longer come to speak to him."

He was no longer the richest and most respected peasant in the village, he was no longer the technician respected for his agricultural knowledge, and he was no longer the village head recognised by the township authorities for his "ability to think clearly about things." (28) He had become a petitioner, that is to say, a kind of beggar who uses rather dishonourable means to get his money back.

In this respect, the sums of money involved represent more than simple quantities; they are above all the measure of the individual's social status. In Chinese society under the economic reforms launched by Deng Xiaoping in the early 1980s with the slogan "enrich yourselves!", social status, which had previously been based in general on "class status" (jieji chengfen 阶级 成分), ${ }^{(29)}$ came to be grounded exclusively on the capacity to get rich. Wu Boliang was respected because he quickly grew rich and rose above his status as a peasant to join the class of tradesmen. But his legal proceedings caused him to lose the most important aspect of status, which cannot be calculated in monetary quantities but rather in the quality of social respect. So it was not only a sum of money that he lost in the proceedings, the money being only the visible part of the iceberg, but above all the dearly won element of face that also represents a value, and he became a controversial figure.

Finally, in 2013, it seems that he recovered some of his energy; he complained less, some money had been returned to him, his health improved a little, and he built a new house in the village for his pesticide and fertiliser store. And then I was told, "There was never a Wu Boliang affair; it was just a communication problem." But it was necessary to wait for 2014 to reach the final solution and bring the affair to a definite end, with the signing of a contract between Wu Boliang and the township.

\section{An analytical overview}

The affair brought up two salient points in the problem of how debt is understood: the role of negotiation and bargaining, and the ability of the agents involved to take action to influence political decisions of the higher levels.

In his introduction to the collective work Lien de vie, nœud mortel - les représentations de la dette en Chine, au Japon et dans le monde indien (The ties of life, a deadly knot - representations of debt in China, Japan, and the Indian world), Charles Malamoud states that for the societies being considered in that volume "[...] debt organises social life, and therefore the life of man himself as a social animal: its presence in the world creates a network of ties that imprison him while simultaneously supporting him $[\ldots]$ it is the weave of life itself [...]" (30). In the contemporary Chinese village of Shiyou, unlike the pre-reform period of Communist rule, when property and the means of production were held in common, indebtedness towards relatives and friends has again become a constant factor of social life. Today it is once again the case, as Michel Cartier notes in his article in the above volume, "Debt and Property in China," that "usury raises no ideological objections," (31) unlike in Judeo-Christian and Islamic cultures. Moreover, according to Viviane Alleton's article in the same volume, there would appear to be no link in the Chinese language between moral debt and material debt. (32) My study of the Wu Boliang affair also shows that the settlement of a debt is not a "moral" issue of good or bad but rather a matter of social relations based on the status of the protagonists. The demand that face be respected, discussed in the previous section, means a respect for Wu Boliang as an individual and likewise for the institution of the township government, but it has no bearing on their moral character. The concept of face rests on the social norm that requires repayment, not because repayment is "good" but because it perpetuates and renews social relations, whereas "non-repayment" amounts to their arrest, a check on this circulation, which on the social level is responsible for a loss of face. Face is the wellspring of honour, and even of life itself, as Wu Boliang says at the end of his letter:

Give me justice and fair treatment! Give me back my life! Give me back my honour!

28. Jin Yongquan, Chen Tong, and Liu Chun, Zuihou de hanzu (The Last Chinese), op. cit., p. 201.

29. After 1949, Communist China registered the whole population in terms of "class status," depending on their economic resources calculated for the three years before 1949. This system would only be fully abandoned in the late 1970s.

30. Charles Malamoud (ed.), Lien de vie, nœud mortel - les représentations de la dette en Chine, au Japon et dans le monde indien (The ties of life, a deadly knot - representations of debt in China, Japan, and the Indian world), Paris, Ed. de l'EHESS, 1988, p. 14.

31. Michel Cartier, "Dette et propriété en Chine" (Debt and property in China), in Charles Malamoud (ed.), Lien de vie, nœud mortel - les représentations de la dette en Chine, au Japon et dans le monde indien, (The ties of life, a deadly knot - representations of debt in China, Japan, and the Indian world), op. cit., p. 27.

32. Viviane Alleton, "Les expressions de la dette et du devoir en chinois" (The expression of debt and duty in Chinese), in Charles Malamoud (ed.), Lien de vie, nœud mortel - les représentations de la dette en Chine, au Japon et dans le monde indien (The ties of life, a deadly knot - representations of debt in China, Japan, and the Indian world), op cit, pp. 169 - 186. 
For Wu Boliang, the non-repayment of the debt by the authorities had the effect of depriving him of his place in society, which he had patiently built with a great deal of effort and energy, in order to rise to the top of his local society. And he should not have been prevented from developing and rising even further. Wu Boliang complains that the development of his family enterprise was blocked, and he told me on several occasions that if not for the trial, he would have continued on his path to becoming a millionaire and would by now be a large property owner. What his complaint raises is not a moral issue; on the contrary, he gives a very concrete list of the financial effects of the debt upon him as well as their direct social consequences. His loss of face was a loss of social status, which cast him down from his eminent position, and in that downfall the "moral" question was secondary.

Neither is there any conflict between "good" and "bad" in the Wu Boliang affair. Not all the cadres were bad, and some of them did their best to move the case file forward. The final responsibility rests with the system, which organises a chain of social relations whose nerve centres had to be jolted into action to finally get the reimbursements paid. Basically, Wu Boliang and the authorities were completely detached from any sense of moral responsibility towards their creditors, whom they simply kept waiting, because in present-day China, just as in former times, one's status as "master of the money" (33) both arises from and is located in the occupation of a superior social position. That makes it possible to manipulate anyone in the lower, subordinate position who might be called a "servant of money." As is shown by the Chinese verb jie 借, which means either "to lend" or "to borrow" according to the context alone, the outward and inward flows of money are of the same order, but the real difference is determined by the social status of the protagonists who are linked hierarchically in a chain of interdependences. Given this situation, it becomes very difficult to step outside the chain, since each level tries to act over the others, as the township seeks funds from the county, which in turn seeks them from the municipality, and the latter from the province, which turns to the state. Each level is only a stage in which the higher levels have the power and capacity to impose their own temporary priorities, whereas the lowest level at the bottom can only have recourse to patience (or disappearance, in extreme cases). For similar reasons, Wu Boliang undertook the legal proceedings not so much through personal courage but because he had been pushed to that extreme; it was because some of his creditors were thinking of taking legal action against him that he was cornered into making his accusation against the township government. Finally the triggering mechanism was perhaps a conflict between people within the credit co-operative and the township government, two bodies normally considered to be associated, and Wu Boliang may have been a pawn in the affair because of his intermediate position between them.

Another essential element is the nature of the bargaining throughout the affair, and the importance of negotiation, and of waiting. Clearly, the lawyers' offices had precise records of the sums owed to Wu Boliang, and the court also conducted its enquiry before pronouncing its verdict. But that did not prevent an official from telling Wu Boliang that he ought to "ask for less." Although that was partly owing to the huge build-up in the interest, it would still be interesting to analyse this bargaining conducted through lengthy negotiations. The authorities bargained, twisted around, and stretched out the affair, while Wu Boliang ran around in search of support, but he too bargained, twisted around, and stretched out the affair in the face of his creditors. They all shared the same attitude and behaviour, making the ultimate creditors wait. China was developing, however, and inflation was rising along with rates of interest on borrowing.

Lastly, Wu Boliang and the township government differed in the way in which they assumed responsibility for the affair. Whereas Wu Boliang contemplated the possibility of bankruptcy, which would have had consequences stretching even into his next reincarnation when he could not "be a man," (34) for many years the authorities showed little concern for the consequences for Wu Boliang. Their higher position in the hierarchy meant that they did not rely on any moral or social authority to govern, but only on their administrative apparatus, their mastery over time, and their authoritarian power, against which individuals, families, and private groups have few resources to support them.

However, the social spaces for such resources do exist. One example is the office of letters and visits. As Isabelle Thireau emphasises in her article on this institution cited above:

The writers of these testimonies expect the local authorities to provide public services and just institutions - that is, institutions that would stop recognising only the special advantages, privileges, and exorbitant power of some (not just in writing but in actual practice). Admittedly, these expectations do not affect the actual political forms of the regime or the contents of its laws and the measures to implement them, but they are nonetheless political, and they participate in the constantly renewed struggle for democracy. ${ }^{(35)}$

Without the verdict of the court, and the support from the office of letters and visits, Wu Boliang's appeals to the township and county governments would have lacked legitimacy. But these institutions do not carry sufficient weight in themselves to get their decisions carried out. Hence the importance of the third agency finally mobilised by Wu Boliang: the media. The article published in a recognised national daily in 2010 was an effective lever in the whole affair.

Nonetheless it took another four years to reach a complete resolution. Perhaps the political anti-corruption movement implemented in China in 2013 may have put strong pressure on the local authorities to take initiative in resolving the cases in their constituencies.

\section{Conclusion}

This case of an individual in a single loan affair shows the weight of the institutions and the relative position of the protagonists facing them. But here again, the weight of the ideology of the family and the hierarchy, which covers all social relations, still imprisons both villagers and cadres in the net of services and status, and it structures their relationship to debt. The individuals are cogs in the institutional machine, and in the last resort they are only distinguished from each other by the amount of face they have

33. According to Michel Cartier "[...] the possessor - or the "master" - of money occupies a higher position because he never appears, so to speak, in the role of petitioner." Michel Cartier, "Dette et propriété en Chine" (Debt and property in China), in Charles Malamoud et al. (eds), Lien de vie, noeud mortel - les représentations de la dette en Chine, au Japon et dans le monde indien (The ties of life, a deadly knot - representations of debt in China, Japan, and the Indian world), op. cit. pp. 17-30.

34. Jin Yongquan, Chen Tong, and Liu Chun, Zuihou de hanzu (The Last Chinese), op. cit., p. 204.

35. Isabelle Thireau, Les ruses de la démocratie en Chine - protester en Chine (Democracy's ruses in China - how the Chinese protest), op. cit., p. 435. 
managed to accumulate or, on the other hand, by the dishonour they have not managed to avoid. But in both cases this shapes their relative status, which rebounds not only on their own persons but above all on the groups to which they belong, namely the family, the village, and the higher administrations. The chain of interdependencies is still very active today; it is very difficult to change it, its constant manipulation by the agents only makes it stronger, with the result that autonomy is not one of this society's confirmed values. Nevertheless, the presence of agents actively working for justice, whether they are the court, the office of letters and visits, or the media, mean that in modern China even peasants with their lower status can aspire to fulfil their dreams; and by the same token, when they come up against established power, either by chance or in their struggle against adversity, there are agencies in place to offer them a basis of support. This support is indispensable but is often insufficient, at least in the short or medium term, as is shown by this study of a case resolved 14 years later.

Looking back at the example of Wu Boliang as an individual, we have to recognise that a major role was played by his intelligence, his courage, his tenacity, and his ability to mobilise his social relations. Despite the difficulties he had to confront, he never expressed any despair or dissidence, even if he directly attributed his ill health to the affair. He always continued to search for resolutions within his own social context. Jin Yongquan's article on his case ends by recalling his words: "I believe - still - in the law; I still believe in the government!"Wu Boliang is a man "of that world," and in the teeth of all adversity he maintained his respect for the law and its authority. The protracted nature of his struggle did not prevent him from retaining his hope in the face of the present social conditions in China. His attachment to his native village, and his continuing concern for it, also show that he always remained a man of his land, perhaps in the full meaning of the term: "the last of the Chinese."

I Translated by Jonathan Hall.

I Catherine Capdeville-Zeng is a Professor of Chinese Anthropology in the Department of Chinese Studies at INALCO (Institut national des langues et civilisations orientales), Paris.

INALCO, 65, rue des Grands Moulins, 75013, Paris, France

(catherine.capdeville@inalco.fr).

Manuscript received on 29 November 2014. Accepted on 30 March 2016. 